\title{
The Causes Analysis of the Air Preheater and Performance Blocking Evaluation of the Measures on the SCR De-NO ${ }_{x}$ Unit
}

\author{
Su Pan ${ }^{1, *}$, Yu Pengfeng ${ }^{1}$, Liu Linbo ${ }^{1}$, Han Jing ${ }^{1}$, and Xiao Shen ${ }^{1}$ \\ ${ }^{1}$ Huadian Electric Power Research Institute Co., LTD., Zhejiang Hangzhou 310030, China
}

\begin{abstract}
In order to solve the problem of abnormal rise of the differential pressure of the revolving air preheater on $300 \mathrm{MW}$ unit, we analysed the causes of abnormal rise of the differential pressure of the air preheater and evaluated performances of control measures, through historical data mining and on-site inspection of the unit. The results show that, with the gradual decrease of environment temperature with the decrease of the exhaust gas temperature, the ashes in flue gas are bound by acid liquid produced by condensation of flue gas, and the adhesion areas of the ammonium bisulfate produced in the denitration process are enlarged. However the original set ash blowing pressure can no longer satisfy the requirements of the air preheater, giving rise to the differential pressure of the air preheater on both sides to rise. The reason of the higher differential pressure of the unilateral air preheater is that the large ammonia injection amount, leading to the increases of ammonia escape of the denitrification system. So the side of the air on preheater ammonium bisulfate type blockage is more serious. After the Measures of Adjusting distribution coefficient of ammonia supply valve on both sides, increasing the dust blowing frequency and pressure of the air preheater, the differential pressure of air preheater on both sides are close to the consistent. The decrease amplitude of the differential pressure of the air preheater on $280 \mathrm{MW}$ is about $300-500 \mathrm{~Pa}$.
\end{abstract}

\section{Introduction}

The air preheater is an important part of the boiler equipment of the coal-fired power plants, which can effectively improve the economical operation of the boiler. However, when the air preheater is clogged, the resistance of the air and flue gas system, and the power consumption of the delivery and induced draft fan ${ }^{[2]}$ will rise. In the extreme case, the air preheater blocking problem could affect the load capacity of the unit and cause the induced draft fan stall ${ }^{[3]}$.

Under the poor condition of the boiler operation, the air preheater is prone to clogging problems, such as the coal as fired with the large ash content ${ }^{[4]}$ and the high sulfur content ${ }^{[5-6]}$, the insufficient air blowing capacity of air preheater ${ }^{[7]}$, the low temperature of the air preheater outlet ${ }^{[8-10]}$, etc. In the recent years, the national thermal power units have implemented ultra-low emission transformation. The large-scale coal-fired units in the operation have gradually retrofitted and adopted the flue gas De- $\mathrm{NO}_{\mathrm{x}}$ systems ${ }^{[11]}$, with the vast majority of the SCR De- $\mathrm{NO}_{\mathrm{x}}$ process. However, the De- $\mathrm{NO}_{\mathrm{x}}$ process appears the sticky ammonium bisulfate ${ }^{[12-14]}$ together with the fly ash, adhering to the air preheater heat exchanger element. The SCR device is also prone to the problem of increased ammonia slip caused by the total or partial excessive ammonia injection ${ }^{[15]}$, which is easy to cause differential pressure rise of the equipment and the blockage problem ${ }^{[16-17]}$.
Aimed at the problem of sudden rise and fall of the differential pressure of the air preheater on the $330 \mathrm{MW}$ unit, the historical data of the air and flue gas system, ammonia supply system and the De- $\mathrm{NO}_{\mathrm{x}}$ system are retrieved. And the on-site inspection is conducted to analyze the cause of abnormal increase of differential pressure in air preheater. During this period, the treatment measures to reduce the differential pressure of the air preheater were implemented and the effects are evaluated. At the same time, the corresponding suggestions are put forward. The specific contents are as follows.

\section{Equipment introduction}

The 330MW unit boiler of the power plant is produced by Wuhan Boiler Factory, model WGZ1100/17.45-5. The type is the subcritical parameter, the natural circulation steam drum, medium speed grinding and the positive pressure direct blowing type pulverizing system, the four corner tangential combustion mode, the Junker three-segment rotary air preheater, burning the bituminous coal, solid waste slag.

The unit was implemented with ultra-low emission modification. The De- $\mathrm{NO}_{\mathrm{x}}$ system adopts the SCR De- $\mathrm{NO}_{\mathrm{x}}$ process and uses a flat catalyst to be placed in the SCR reactor in the flue gas system. The Junker three-segment rotary air preheater is arranged by Howden Hua Engineering Co., Ltd., and the design 
model is 29VNT1950. The hot-end heat exchange component is made of the low-carbon steel, and the cold-end heat exchange component is the low-carbon steel enamel. The spindle of the air preheater is arranged vertically and the flue gas and air exchange heat in a countercurrent manner.

\section{Overview of the differential pressure increase of the air preheater}

The variation of the differential pressure of the air preheaters on both sides is analyzed. Figure 1 shows the differential pressure curve of the flue gas side of the air preheater under different loads (after the last start), and Fig. 2 shows the differential pressure of the flue gas side of the air preheater and the secondary air (280 MW). The differential pressure data of the air preheater were taken from the air preheater without soot blowing and the load was stable.

It can be seen from Fig. 1 that after the unit started, the differential pressure of the flue gas side of the $A / B$ air preheater was 0.97 and $1.13 \mathrm{kPa}$ respectively on 330 MW, which was lower than the design value of the flue gas side resistance of the air preheater (the maximum output condition is $1.25 \mathrm{kPa}$ ). According to the flue gas side differential pressure curve of the air preheater to calculate $280 \mathrm{MW}$ load, the A/B air preheater flue gas side differential pressure was 0.77 and $0.98 \mathrm{kPa}$ respectively.

The variation of the differential pressure of the air preheater within the last 5 months of the last 5 days of the start is analyzed. The number of days is the basic unit and is named 1d-30d. It can be seen from Fig. 2 that the differential pressure of the air preheater was slowly increased in the last four months of the start of the machine, and the differential pressure of the flue gas side of the $\mathrm{A} / \mathrm{B}$ air preheater was increased by 0.59 and $0.14 \mathrm{kPa}$, respectively. From $1 \mathrm{~d}$ to $15 \mathrm{~d}$, the variation of the flue gas side differential pressure and the secondary air differential pressure of the A air preheater was not large, and the decreasing trend occurred in some time periods, which is related to the time interval between the data selection time and the end time of soot blowing. Meanwhile, the variation of the flue gas side differential pressure and the secondary air differential pressure of the $\mathrm{B}$ air preheater showed a tendency to increase slowly. From $15 \mathrm{~d}$ to $26 \mathrm{~d}$, the variation of the flue gas side differential pressure and the secondary air differential pressure of the A air preheater showed a slow increase trend, and the variation of the flue gas side differential pressure and the secondary air differential pressure of the A air preheater increased abnormally, with the values of 2.06 and $1.03 \mathrm{kPa}$ respectively. From this, it is determined that there was a significant blockage problem in the B air preheater, and the cause of the blockage is now analyzed.

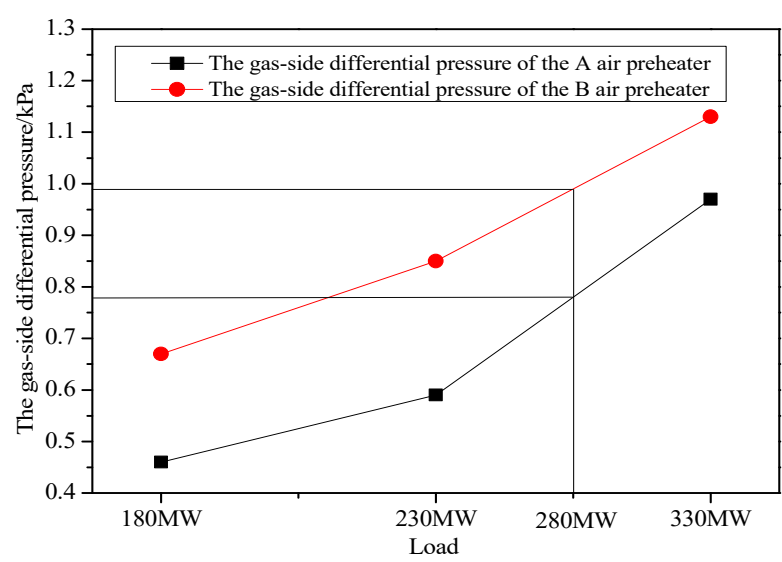

Fig.1. The gas-side differential pressure of the air preheater vs. different loads (after the last startup)

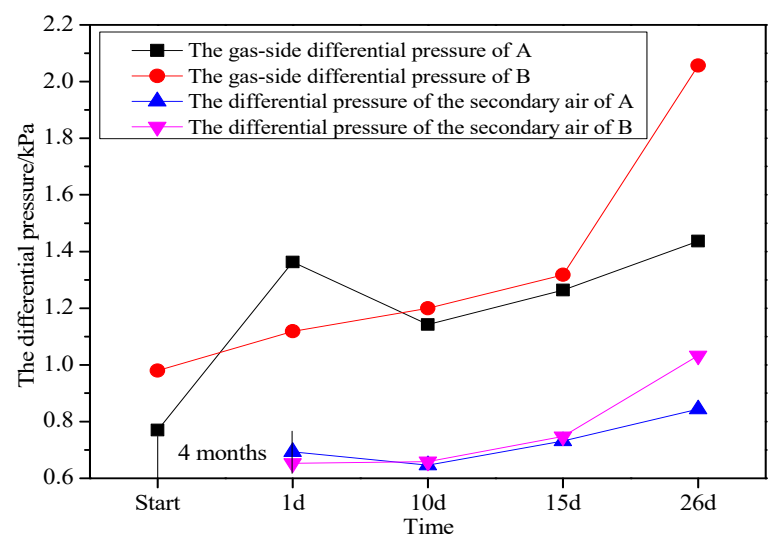

Fig.2. The gas-side differential pressure of the air preheater and the differential pressure of the secondary air (280MW)

\section{Cause Analysis}

\subsection{Analysis of coal quality data in coal}

Selected the time period 1 (the differential pressure of the air preheater was normal, $1 \mathrm{~d}$ to $5 \mathrm{~d}$ ) and the time period 2 (the differential pressure of the air preheater was abnormally increased, $22 \mathrm{~d}$ to $26 \mathrm{~d}$ ), the coal as fired quality data are comparatively analyzed. Table 1 is the comparison the average value of coal as fired quality data in the different time limit. It can be seen from the table that the coal quality data were close to the designed coal, and the coal quality data such as the base sulfur and the received base low heat were well consistent. So we can exclude the influence of the differential pressure of the air preheater due to the change of coal quality in the furnace.

Table 1. Comparison of different types of coal burned in different time periods

\begin{tabular}{ccccc}
\hline \multirow{2}{*}{ Item } & unit & Design coal & $\begin{array}{c}\text { Time period } \\
1\end{array}$ & $\begin{array}{c}\text { Time period } \\
2\end{array}$ \\
\hline$M_{\text {ar }}$ & $\%$ & 9.5 & 9.57 & 8.63 \\
$M_{\text {ad }}$ & $\%$ & 3.00 & 3.05 & 2.61 \\
$A_{\text {ar }}$ & $\%$ & 23.55 & 22.47 & 23.44 \\
$V_{\text {daf }}$ & $\%$ & 34.12 & 37.76 & 38.25 \\
\hline
\end{tabular}




\begin{tabular}{ccccc}
\hline \multirow{2}{*}{ Item } & unit & Design coal & Time period & Time period \\
& & 1 & 2 \\
\hline$S_{\text {t.ar }}$ & $\%$ & 0.68 & 0.92 & 0.92 \\
$Q_{\text {net.ar }}$ & $\%$ & 20170 & 20683 & 20768 \\
\hline
\end{tabular}

\subsection{Analysis of the air preheater soot blowing}

The pressure of the air preheater soot blowing is $1.0 \mathrm{MPa}$ (the manufacturer's specified value is $1.0-1.5 \mathrm{MPa}$ ), and the frequency of soot blowing is 1 time per shift. The parameter changes of the air preheater soot blowing operation are shown under the $25 \mathrm{~d}$, and table 2 is the parameter data of the air preheater soot blowing. Under the $260 \mathrm{MW}$ load, in the statistical soot blowing $1 \mathrm{~h}$ time, the flue gas side differential pressure drop value of the A air preheater was $170 \mathrm{~Pa}$, and the flue gas side differential pressure drop value of the A air preheater was $410 \mathrm{~Pa}$, indicating that the single air preheater soot blowing could be effective and the differential pressure of the flue gas side of the air preheater was reduced. However, the flue gas side differential pressure of the $\mathrm{B}$ air preheater had a rebound problem. After $11 \mathrm{~h}$, under the same unit load, the differential pressure of the $\mathrm{B}$ air preheater increased by $210 \mathrm{~Pa}$, and the differential pressure of the A preheater increased by $100 \mathrm{~Pa}$ merely. The above description shows that when the differential pressure of the air preheater rose abnormally, the air preheater can reduce the differential pressure of the air preheater. However, after stopped the air preheater soot blowing, the differential pressure of the air preheater had obvious rebound problem, and the B air preheater had a faster blocking.

Table 2. The parameters change under the operation of air preheater ash blowing

\begin{tabular}{|c|c|c|c|c|}
\hline & Parameter & \multicolumn{2}{|c|}{ Unit } & alue \\
\hline 1 & Soot blowing & - & Yes & No \\
\hline 2 & Date & $\mathrm{d}$ & $25 d$ & $25 \mathrm{~d}$ \\
\hline 3 & Time & - & $10: 12-11: 12$ & $22: 45$ \\
\hline 4 & Soot blowing time & $\min$ & $1 \mathrm{~h}$ & \\
\hline 5 & Load & MW & 260 & 260 \\
\hline 6 & Soot blowing pressure & $\mathrm{MPa}$ & 1.0 & \\
\hline 7 & $\begin{array}{l}\text { Pre-the flue gas side } \\
\text { differential pressure } \\
\text { of the A air preheater }\end{array}$ & $\mathrm{Pa}$ & 1370 & \\
\hline 8 & $\begin{array}{l}\text { Post- the flue gas side } \\
\text { differential pressure } \\
\text { of the A air preheater }\end{array}$ & $\mathrm{Pa}$ & 1200 & 1300 \\
\hline 9 & $\begin{array}{c}\text { The flue gas side } \\
\text { differential pressure } \\
\text { drop value of the A air } \\
\text { preheater }\end{array}$ & $\mathrm{Pa}$ & 170 & \\
\hline 10 & $\begin{array}{l}\text { Pre-the flue gas side } \\
\text { differential pressure } \\
\text { of the B air preheater }\end{array}$ & $\mathrm{Pa}$ & 1930 & \\
\hline 11 & $\begin{array}{l}\text { Post- the flue gas side } \\
\text { differential pressure } \\
\text { of the B air preheater }\end{array}$ & $\mathrm{Pa}$ & 1520 & 1730 \\
\hline 12 & $\begin{array}{c}\text { The flue gas side } \\
\text { differential pressure } \\
\text { drop value of the B air } \\
\text { preheater }\end{array}$ & $\mathrm{Pa}$ & 410 & \\
\hline
\end{tabular}

\subsection{Analysis of resistance change of flue gas system}

The historical operation data are retrieved and the 280MW load time period is selected. Under the conditions of without the boiler and air preheater soot blowing, the comparison of the partial the flue gas system resistance between the operation condition 1 $(27 \mathrm{~d}$, the differential pressure of the air preheater is high) and the operation condition $2(1 \mathrm{~d}$, the differential pressure of the air preheater is normal). The partial the resistance of the flue gas system includes the differential pressure of the electric dust, the differential pressure between the air preheater outlet and the electric precipitator outlet, and the differential pressure of the De- $\mathrm{NO}_{x}$ system.

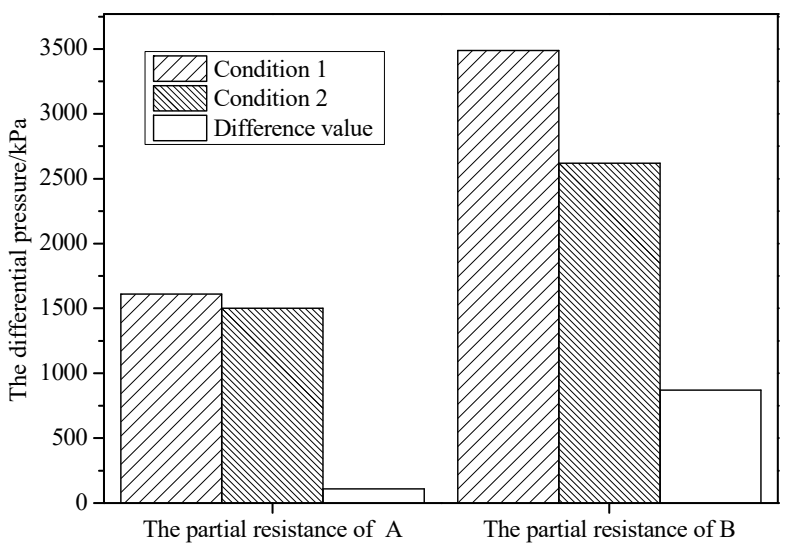

Fig.3. Partial resistance comparison of the flue gas system under the two conditions

Figure 3 shows the partial resistance comparison of the flue gas system under the two operating conditions, and Table 3 shows the resistance comparison data of the electric precipitation and $\mathrm{De}-\mathrm{NO}_{\mathrm{x}}$ system. The partial resistance of the A flue gas system did not change much, and the operating condition 1 increased by $110 \mathrm{~Pa}$ compared with the operating condition 2 , mainly due to the increase of the differential pressure of the electric precipitation. The partial resistance of the B flue gas system increased, and the operating condition 1 increased by $870 \mathrm{~Pa}$ compared with the working condition 2 , mainly due to the increase of the differential pressure between the air preheater outlet and the electric precipitator outlet. The partial resistance of the $\mathrm{B}$ flue gas system increased by less than $900 \mathrm{~Pa}$, which only caused a very small amount of flue gas that should have passed from the B flue passage to be transferred to the A flue passage. So there was no correlation with the abnormal increase of the differential pressure of the $\mathrm{B}$ air preheater.

Table 3. The comparison of electric dust removal and denitrification system resistance

\begin{tabular}{ccccc}
\hline Parameter & unit & $\begin{array}{c}\text { Condition } \\
1\end{array}$ & $\begin{array}{c}\text { Condition } \\
2\end{array}$ & $\begin{array}{c}\text { Difference } \\
\text { value }\end{array}$ \\
\hline The differential & & & & \\
$1 \quad \begin{array}{c}\text { pressure of the } \\
\text { A electric } \\
\text { precipitator }\end{array}$ & $\mathrm{Pa}$ & 984 & 820 & 164 \\
\hline
\end{tabular}




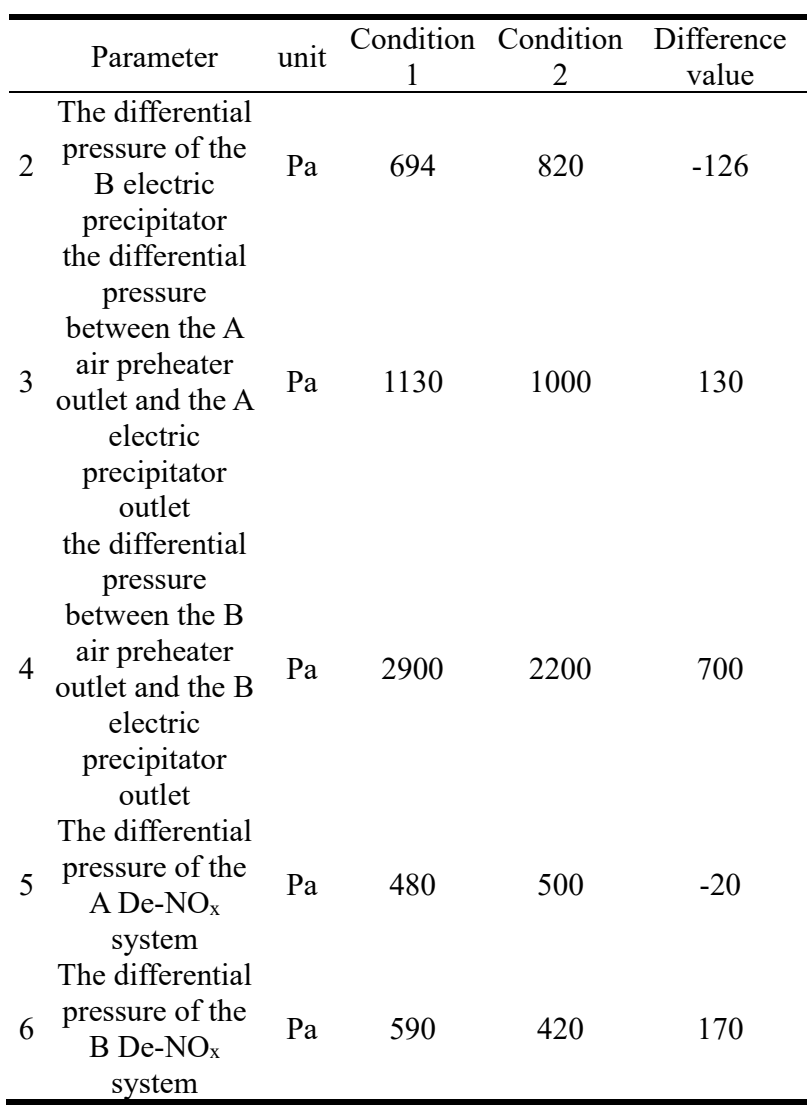

\subsection{Analysis of the exhaust gas temperature and environmental temperature variation}

The flue gas acid dew point is analyzed, and the smoke acid dew point temperature is calculated using the algorithm recommended by the boiler unit thermal calculation standard method from the former Soviet Union $^{[18-19]}$. The formula is as follows:

$$
t_{\mathrm{sld}}=t_{\mathrm{ld}+} \beta *\left(S_{z s}\right)^{1 / 3} / 1.05^{\left(\alpha \mathrm{fh}^{*} A z \mathrm{zs}\right)}
$$

In the formula, $t_{\text {sld }}-$ Flue gas dew point temperature, $\% ; t_{\mathrm{ld}}-$ Pure water vapor dew point temperature, \%; When the excess air coefficient is $1.2-1.25, \beta=121$, and when the excess air coefficient is 1.4-1.5, $\beta=129 ; \alpha_{\mathrm{fh}}-$ Ash share, pulverized coal furnace takes $0.9 ; \mathrm{A}_{\mathrm{zs}}$ - Converted ash, $\% ; S_{\mathrm{zs}}-$ Sonvert sulfur, $\%$.

The pure water vapor dew point temperature is calculated from the water vapor volume fraction in the flue gas, and the pure water vapor dew point temperature $t_{\mathrm{ld}}$ is calculated as follows:

$$
\begin{gathered}
t_{\mathrm{ld}}=-1.2102+8.4064 * \phi \mathrm{H}_{2} \mathrm{O}-0.4749 *(\phi \\
\left.\mathrm{H}_{2} \mathrm{O}\right)^{2}+0.01042\left(\phi \mathrm{H}_{2} \mathrm{O}\right)^{3} \\
\phi \mathrm{H}_{2} \mathrm{O} \text { - } \text { water vapor volume fraction, } \% \text {, from }
\end{gathered}
$$
"Boiler Design Manual"[19]. The coal as fired under time period 1 and time period 2 was close to the coal quality data of the designed coal type. Due to without the elemental analysis data of the coal as fired under the two time periods, we calculate the flue gas acid dew point temperature of the air preheater outlet according to the analysis data of the designed coal type elements, combined with the boiler operation data and the ash flammable material data. Table 4 is the steam volume fraction calculation of the air preheater outlet. In the two time periods, the average value of fly ash and slag combustibles is $2.56 \%$ and $4.44 \%$, and the average air excess coefficient of the air preheater outlet is 1.44. According to the calculation method of air volume and smoke volume in "Boiler Design Manual", the dry flue gas volume and the flue gas steam volume of the preheater outlet were $7.84 \mathrm{~m}^{3} / \mathrm{kg}$ and $0.55 \mathrm{~m}^{3} / \mathrm{kg}$ respectively. So the steam pre-exhaust steam volume fraction was about $6.55 \%$.

Table 4. The calculation table of the steam volume fraction of the air preheater outlet

\begin{tabular}{ccc}
\hline Parameter & Unit & value \\
\hline Design coal- $C_{\mathrm{ar}}$ & $\%$ & 53.73 \\
Design coal- $H_{\mathrm{ar}}$ & $\%$ & 3.11 \\
$\quad \begin{array}{c}\text { Design coal- } O_{\mathrm{ar}} \\
\text { Design coal- } N_{\mathrm{ar}}\end{array}$ & $\%$ & 0.90 \\
$\begin{array}{c}\text { Excess air coefficient of the } \\
\text { air preheater outlet }\end{array}$ & - & 8.53 \\
$\begin{array}{c}\text { Modified theoretical dry air } \\
\quad \text { volume }\end{array}$ & $\mathrm{m}^{3} / \mathrm{kg}$ & 5.53 \\
$\quad \begin{array}{c}\text { Modified theoretical dry } \\
\text { smoke volume }\end{array}$ & $\mathrm{m}^{3} / \mathrm{kg}$ & 5.43 \\
$\begin{array}{c}\text { Dry smoke volume of the air } \\
\text { preheater outlet }\end{array}$ & $\mathrm{m}^{3} / \mathrm{kg}$ & 7.84 \\
$\begin{array}{c}\text { Flue gas water vapor volume } \\
\text { of the air preheater outlet }\end{array}$ & $\mathrm{m}^{3} / \mathrm{kg}$ & 0.55 \\
$\begin{array}{c}\text { Steam volume fraction of the } \\
\text { air preheater outlet }\end{array}$ & $\%$ & 6.55 \\
\hline According to the proximate & & \\
\hline
\end{tabular}

According to the proximate analysis and calorific value of coal as fired, the flue gas dew point of the air preheater outlet is analyzed. Table 5 shows the dew point temperature of the air preheater outlet. According to formula(1), the excess air coefficient was 1.4-1.5, $\beta$ was 129 , and the acid dew point temperatures of time period 1 and time period 2 were respectively calculated to be $103.28^{\circ} \mathrm{C}$ and $102.73^{\circ} \mathrm{C}$.

Table 5. The exhaust gas dew-point temperature at of the air preheater outlet

\begin{tabular}{cccc}
\hline Parameter & unit & $\begin{array}{c}\text { Time } \\
\text { period 1 }\end{array}$ & $\begin{array}{c}\text { Time } \\
\text { period 2 }\end{array}$ \\
\hline$M_{\mathrm{t}}$ & $\%$ & 9.57 & 8.63 \\
$M_{\mathrm{ad}}$ & $\%$ & 3.05 & 2.61 \\
$A_{\mathrm{ar}}$ & $\%$ & 22.47 & 23.44 \\
$S_{\mathrm{ar}}$ & $\%$ & 0.92 & 0.92 \\
$Q_{\mathrm{net}, \mathrm{ar}}$ & $\%$ & 20683 & 20768 \\
Converting sulfur & $\%$ & 0.19 & 0.19 \\
Converting ash & $\%$ & 4.54 & 4.72 \\
Air excess coefficient & $/$ & 1.44 & 1.45 \\
$\beta$ & $/$ & 129 & 129 \\
Steam volume fraction & & & \\
of the air preheater & $\%$ & 6.55 & 6.55 \\
outlet & & & \\
Water vapor pure dew & & & \\
point temperature of & ${ }^{\circ} \mathrm{C}$ & 42.96 & 42.96 \\
the air preheater outlet & & & \\
Flue gas dew point & & & \\
temperature of air & ${ }^{\circ} \mathrm{C}$ & 103.28 & 102.73 \\
preheater outlet & & & \\
\hline
\end{tabular}

The historical data is used to compare the exhaust gas temperature and the ambient temperature average value of time period 1 (the normal differential pressure 
of the air preheater, $1 \mathrm{~d}$ to $5 \mathrm{~d}$ ) and time period 2 (the differential pressure of the air preheater abnormally increased, 22d to $26 \mathrm{~d}$ ).

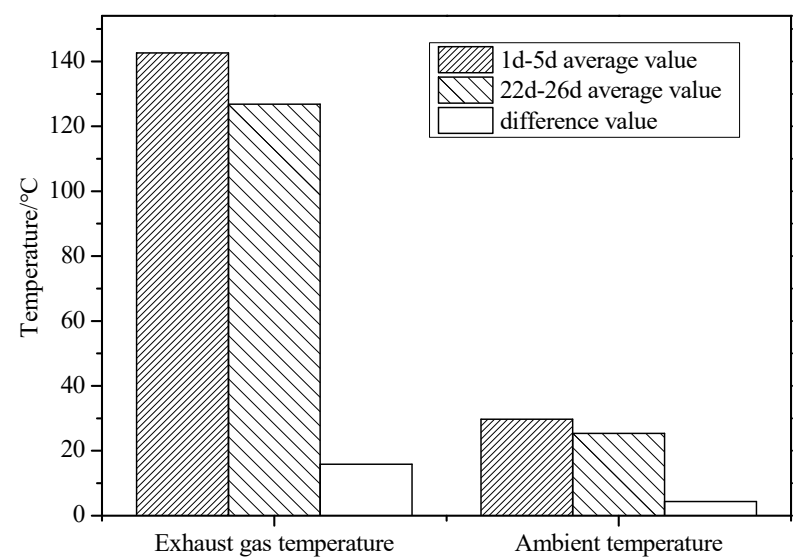

Fig. 4. Comparison of the exhaust gas average temperature and the ambient average temperature under the two time periods

Figure 4 shows the exhaust gas temperature average value and the ambient temperature average value during the two time periods. Table 6 shows the exhaust gas temperature average value and the ambient temperature average value in the partial dates. The mean exhaust gas temperature average value in time period 1 was $142.64^{\circ} \mathrm{C}$, and the exhaust gas temperature average value in time period 2 was $126.81{ }^{\circ} \mathrm{C}$. As the temperature enters autumn, the ambient temperature gradually decreased. The exhaust gas temperature average value in time period 2 was lower than the exhaust temperature average value in time period 1 by about $15.83^{\circ} \mathrm{C}$. Compared the exhaust gas temperature with the flue gas acid dew point temperature in two time periods, it is found that the instantaneous exhaust gas temperature in time period 1 was all greater than the flue gas acid dew point temperature of the air preheater outlet, and the instantaneous exhaust gas temperature in time period 2 was less than the flue gas acid dew point temperature of the air preheater outlet by about $32 \%$, indicating that the flue gas condensation occurred in part of the time period 2 to produce an acid liquid, which adhered to the surface of the air preheater element bound the ash in the flue gas, excepting the normal accumulation part of the ash. With the more the product accumulated, the original soot blowing pressure of the air preheater can no longer meet the soot blowing requirements, resulting in the problem of ash blocking in the air preheater. In addition, compared the time period 1 with the time period 2, as the exhaust gas temperature was lowered, the area of the ammonium sulfate ammonium sulfate adhered during the De- $\mathrm{NO}_{\mathrm{x}}$ process was enlarged, to be more likely to clogging problems of the air preheater.

Table 6. The data of the exhaust gas average temperature and the ambient average temperature

\begin{tabular}{ccccc}
\hline date & $\begin{array}{c}\text { Exhaust gas } \\
\text { temperature } /{ }^{\circ} \mathrm{C}\end{array}$ & date & $\begin{array}{c}\text { Exhaust } \\
\text { gas } \\
\text { temperature } \\
/{ }^{\circ} \mathrm{C}\end{array}$ & Difference $/{ }^{\circ} \mathrm{C}$ \\
\hline 1d & 136.89 & $22 \mathrm{~d}$ & 127.62 & 9.27 \\
2d & 142.60 & $23 \mathrm{~d}$ & 126.44 & 16.16 \\
$3 \mathrm{~d}$ & 143.18 & $24 \mathrm{~d}$ & 128.52 & 14.66 \\
$4 \mathrm{~d}$ & 141.06 & $25 \mathrm{~d}$ & 129.13 & 11.93 \\
$5 \mathrm{~d}$ & 149.47 & $26 \mathrm{~d}$ & 122.33 & 27.14 \\
\hline date & $\begin{array}{c}\text { Ambient } \\
\text { temperature } /{ }^{\circ} \mathrm{C}\end{array}$ & $\mathrm{date}$ & $\begin{array}{c}\text { Ambient } \\
\text { temperature }\end{array}$ & Difference $/{ }^{\circ} \mathrm{C}$ \\
\hline $1 \mathrm{~d}$ & 29.24 & $22 \mathrm{~d}$ & 24.84 & 4.40 \\
2d & 28.97 & $23 \mathrm{~d}$ & 25.80 & 3.17 \\
$3 \mathrm{~d}$ & 30.73 & $24 \mathrm{~d}$ & 26.07 & 4.66 \\
$4 \mathrm{~d}$ & 30.83 & $25 \mathrm{~d}$ & 26.37 & 4.46 \\
$5 \mathrm{~d}$ & 28.90 & $26 \mathrm{~d}$ & 23.82 & 5.08 \\
\hline
\end{tabular}

\subsection{Operational analysis of the $\mathrm{De}-\mathrm{NO}_{\mathrm{x}}$ system}

The operation of the De- $\mathrm{NO}_{\mathrm{x}}$ system is analyzed, and table 7 shows the operating parameters of the De- $\mathrm{NO}_{\mathrm{x}}$ system on $280 \mathrm{MW}$ load. As can be seen from the table, for example of the De- $\mathrm{NO}_{\mathrm{x}}$ operation conditions of $15 \mathrm{~d}$ and $26 \mathrm{~d}$, the $\mathrm{NO}_{\mathrm{x}}$ concentration of the De- $\mathrm{NO}_{\mathrm{x}}$ system inlet was less than or close to the $\mathrm{NO}_{\mathrm{x}}$ concentration of the $\mathrm{A}$ De- $\mathrm{NO}_{\mathrm{x}}$ system inlet, and the $\mathrm{NO}_{\mathrm{x}}$ concentration of the B De-NO $\mathrm{NO}_{\mathrm{x}}$ system outlet was lower than the $\mathrm{NO}_{\mathrm{x}}$ concentration of the A De- $\mathrm{NO}_{\mathrm{x}}$ system outlet. Under normal conditions, the ammonia supply of the $\mathrm{B}$ side should be less than or close to the ammonia supply amount of the A side. However, the actual B De- $\mathrm{NO}_{\mathrm{x}}$ ammonia supply valve opening degree and ammonia supply flow rate were larger than the $\mathrm{A}$ De- $\mathrm{NO}_{\mathrm{x}}$ ammonia supply valve opening degree and the ammonia supply flow rate, indicating that the $\mathrm{B}$ De- $\mathrm{NO}_{\mathrm{x}}$ ammonia injection amount was large. It was more likely to cause an increase in ammonia slip in the $\mathrm{B}$ De- $\mathrm{NO}_{\mathrm{x}}$ system, which may cause the differential pressure of the $\mathrm{B}$ air preheater to be higher than the differential pressure of the A air preheater.

Table 7. Operation parameters of the De-NO ${ }_{x}$ system $(280 \mathrm{MW})$

\begin{tabular}{|c|c|c|c|}
\hline \multirow{2}{*}{ Parameter } & \multirow{2}{*}{ Unit } & \multicolumn{2}{|c|}{ Date } \\
\hline & & $26 \mathrm{~d}$ & $15 \mathrm{~d}$ \\
\hline $\begin{array}{l}\mathrm{NO}_{\mathrm{x}} \text { concentration of the } \\
\text { A De-NOx system inlet }\end{array}$ & $\mathrm{mg} / \mathrm{Nm}^{3}$ & 367.01 & 333.97 \\
\hline $\begin{array}{l}\mathrm{NO}_{\mathrm{x}} \text { concentration of the } \\
\mathrm{B} \text { De-NO } \mathrm{NO}_{\mathrm{x}} \text { system inlet }\end{array}$ & $\mathrm{mg} / \mathrm{Nm}^{3}$ & 354.14 & 334.75 \\
\hline $\begin{array}{l}\mathrm{NO}_{\mathrm{x}} \text { concentration of the } \\
\text { A De-NO } \mathrm{N}_{\mathrm{x}} \text { system outlet }\end{array}$ & $\mathrm{mg} / \mathrm{Nm}^{3}$ & 24.25 & 31.72 \\
\hline $\begin{array}{l}\mathrm{NO}_{\mathrm{x}} \text { concentration of the } \\
\mathrm{B} \text { De-NO } \mathrm{NO}_{\mathrm{x}} \text { system outlet }\end{array}$ & $\mathrm{mg} / \mathrm{Nm}^{3}$ & 13.07 & 15.37 \\
\hline $\begin{array}{c}\text { The A De-NOx ammonia } \\
\text { supply valve opening } \\
\text { degree }\end{array}$ & $\%$ & 42.45 & 38.22 \\
\hline The B De-NO ${ }_{x}$ ammonia & $\%$ & 47.09 & 45.65 \\
\hline
\end{tabular}




\begin{tabular}{|c|c|c|c|}
\hline \multirow{2}{*}{ Parameter } & \multirow{2}{*}{ Unit } & \multicolumn{2}{|c|}{ Date } \\
\hline & & $26 \mathrm{~d}$ & $15 \mathrm{~d}$ \\
\hline $\begin{array}{c}\text { supply valve opening } \\
\text { degree }\end{array}$ & & & \\
\hline $\begin{array}{l}\text { The A De-NOx ammonia } \\
\text { supply flow rate }\end{array}$ & $\mathrm{Nm}^{3} / \mathrm{h}$ & 108.85 & 95.19 \\
\hline $\begin{array}{l}\text { The B De-NOx ammonia } \\
\text { supply flow rate }\end{array}$ & $\mathrm{Nm}^{3} / \mathrm{h}$ & 114.15 & 107.36 \\
\hline $\begin{array}{l}\mathrm{NO}_{\mathrm{x}} \text { average value of the } \\
\text { absorption tower }\end{array}$ & $\mathrm{mg} / \mathrm{Nm}^{3}$ & 33.94 & 35.40 \\
\hline
\end{tabular}

\section{Measures and effect evaluation}

\subsection{Measures}

We changed the frequency of air preheater soot blowing from 1 to 2 times per shift, and increased the air preheater soot pressure from 1.0MPa to $1.5 \mathrm{MPa}$. On the other hand, in the case of the $\mathrm{NO}_{\mathrm{x}}$ concentration at the chimney inlet not exceeding the standard, We adjusted the distribution coefficient of the ammonia supply valve on the A/B side, and adjusted the opening degree of the ammonia adjustment door to the same or close to the opening degree, if the $\mathrm{NO}_{\mathrm{x}}$ concentration at the inlet of the De- $\mathrm{NO}_{\mathrm{x}}$ system on both sides was the same. Table 8 shows the exhaust gas temperature average value and the ambient temperature average value during the partial time. After the implementation of the treatment measures, the differential pressure of the air preheater dropped significantly and there was no obvious rebound of the differential pressure of the air preheater. At 28d/05:00, the differential pressure of the air preheater on both sides were nearly the same.

Table 8. The mean of the exhaust gas temperature and the ambient temperature

\begin{tabular}{|c|c|c|c|c|c|}
\hline & Parameter & Unit & & Value & \\
\hline 1 & Soot blowing & - & Yes & Yes & Yes \\
\hline 2 & Date & - & $27 d$ & $27 d$ & $28 \mathrm{~d}$ \\
\hline 3 & Time & - & $\begin{array}{l}17: 12- \\
18: 12\end{array}$ & $\begin{array}{l}18: 30- \\
19: 30\end{array}$ & $12: 20$ \\
\hline 4 & $\begin{array}{l}\text { Soot blowing } \\
\text { time }\end{array}$ & $\mathrm{H}$ & 1 & 1 & - \\
\hline 5 & Load & MW & 250 & 250 & 250 \\
\hline 6 & Blowing pressure & $\mathrm{MPa}$ & 1.0 & 1.5 & 1.5 \\
\hline 7 & $\begin{array}{l}\text { The differential } \\
\text { pre-pressure of } \\
\text { the A air preheater }\end{array}$ & $\mathrm{Pa}$ & 1510 & 1220 & - \\
\hline 8 & $\begin{array}{l}\text { The differential } \\
\text { post-pressure of } \\
\text { the A air preheater }\end{array}$ & $\mathrm{Pa}$ & 1200 & 1200 & 1131 \\
\hline 9 & $\begin{array}{l}\text { The differential } \\
\text { pressure } \\
\text { decreased value } \\
\text { of the A air } \\
\text { preheater }\end{array}$ & $\mathrm{Pa}$ & 300 & 20 & - \\
\hline 10 & $\begin{array}{c}\text { The differential } \\
\text { pre-pressure of } \\
\text { the B air } \\
\text { preheater }\end{array}$ & $\mathrm{Pa}$ & 2040 & 1630 & - \\
\hline 11 & $\begin{array}{c}\text { The differential } \\
\text { post-pressure of } \\
\text { the B air }\end{array}$ & $\mathrm{Pa}$ & 1580 & 1530 & 1195 \\
\hline
\end{tabular}

\begin{tabular}{|c|c|c|c|c|c|}
\hline & Parameter & Unit & & Value & \\
\hline 12 & $\begin{array}{c}\text { preheater } \\
\text { The differential } \\
\text { pressure } \\
\text { decreased value } \\
\text { of the B air } \\
\text { preheater }\end{array}$ & $\mathrm{Pa}$ & 460 & 100 & - \\
\hline
\end{tabular}

\subsection{Effect evaluation}

The effect of reducing the differential pressure of the air preheater is evaluated. After the differential pressure of the air preheater on both sides was close to the same at 28d/05:00, the differential pressure of the B air preheater did not exceed $1.7 \mathrm{kPa}$ on the $280 \mathrm{MW}$ load, for the air preheater soot blowing and non-blowing conditions. And most of them were at about $1.5 \mathrm{kPa}$, indicating that the problem of the high differential pressure of the $\mathrm{B}$ air preheater was significantly alleviated after the implementation of the treatment measures. The historical data of the pre-/post-conditions of the measures were selected for comparative analysis. And the operating conditions of $26 \mathrm{~d}$ and $28 \mathrm{~d}$ were taken as an example, excepting for the soot blowing time. Table 9 shows the evaluation parameters of the treatment measures. It can be seen from the table that the differential pressure of the $\mathrm{B}$ air preheater decreased by about $480 \mathrm{~Pa}$, and the differential pressure of the $\mathrm{A}$ air preheater did not change much, but increased by $120 \mathrm{~Pa}$, which was related to the time interval between the data selection time and the end time of the soot blowing. As described above, after the implementation of the treatment measures, the differential pressure of the air preheaters on both sides was nearly the same, and the differential pressure of the $\mathrm{B}$ air preheater was significantly reduced, with the reduction about 300-500Pa.

Table 9. The evaluation parameters of the effect of the treatment measures

\begin{tabular}{cccc}
\hline Parameter & unit & $\begin{array}{c}\text { Pre-measure } \\
\text { condition }\end{array}$ & $\begin{array}{c}\text { Post-measure } \\
\text { condition }\end{array}$ \\
\hline Date & - & $26 \mathrm{~d}$ & $28 \mathrm{~d}$ \\
Time & - & $10: 00$ & $19: 12$ \\
$\begin{array}{c}\text { Load } \\
\text { The differential }\end{array}$ & $\mathrm{MW}$ & 280 & 280 \\
pressure of the A \\
air preheater \\
$\begin{array}{c}\text { The differential } \\
\text { pressure of the B } \\
\text { air preheater }\end{array}$ & $\mathrm{kPa}$ & 1.44 & 1.58 \\
\hline
\end{tabular}

It is recommended to adjust the ammonia supply amount according to the $\mathrm{NO}_{\mathrm{x}}$ concentration at the inlet and outlet of the De- $\mathrm{NO}_{\mathrm{x}}$ system on both sides to ensure the ammonia supply amount on both sides of the De- $\mathrm{NO}_{\mathrm{x}}$ system is reasonable. If the conditions permit, the frequency of the air preheater should be changed from 1 to 2 times per shift, and the soot blowing pressure of the air preheater should be increased from 1.0MPa to $1.5 \mathrm{MPa}$. 


\section{Conclusions}

(1) The reason for the increase of the differential pressure of the air preheaters on both sides is that the acid liquid generated by the condensation of the flue gas adhered to the ash in the flue gas and was bonded to the element surface of the air preheater, with the ambient temperature and exhaust gas temperature decreasing lowered recently. So the initial soot blowing pressure of the air preheater can no longer satisfy the soot blowing requirements, resulting in an increase in the differential pressure of the air preheater. In addition, as the exhaust gas temperature was lowered, the area with the ammonium sulfate ammonium sulfate was enlarged during the De-NO $\mathrm{N}_{\mathrm{x}}$ process, to be more prone to blockage problems.

(2) The reason for the abnormal increase in the differential pressure of the $\mathrm{B}$ air preheater is in addition to the reasons described in Conclusion 1, including the $\mathrm{B}$ De- $\mathrm{NO}_{\mathrm{x}}$ ammonia injection amount was large. It was more likely to cause an increase in ammonia slip in the $\mathrm{B}$ De- $\mathrm{NO}_{\mathrm{x}}$ system, which may cause the differential pressure of the $B$ air preheater to be higher than the differential pressure of the A air preheater.

After adjusting the distribution coefficient of the ammonia supply valve on the $\mathrm{A} / \mathrm{B}$ side, increasing the frequency and pressure of soot blowing of the air preheater, the differential pressure of the air preheaters on both sides was nearly the same, and the differential pressure of the $\mathrm{B}$ air preheater was significantly reduced, with the reduction about $300-500 \mathrm{~Pa}$.

\section{Acknowledgement}

The authors gratefully acknowledge financial support from 2017-2018 China Huadian Corporation Science and Technology Project (CHDKJ18-02-66).

\section{References}

1. S.G. Li, L.M. Han. Huadian Technology, 39(12): 56-61 (2017)

2. Z.Q. He, G.H. Ren, L.M. Qi. Power System Engineering, 25(3): 47-50 (2009)

3. P. Cui. Inner Mongolia Electric Power, 25(3): 47-50 (2009)

4. X.U. Duan. Huadian Technology, 37(5): 50-52 (2015)

5. D.L. Zhu, J.F. Yang, Z.Q. Yan, H. Liu. Boiler Technology, 47(4), 74-77 (2016)

6. R.T. Hui, F. Wei, B.D. Wang, A.Y. Yang. Electric Power, 47(10): 110-112 (2014)

7. J.J. Shen, Z.Q. He. Environmental Protection Science, 43(1): 88-91(2017)

8. P. Zheng. Journal of Chongqing Electric Power College, 14(4): 1-4 (2009)

9. S.X. Lu, R. Dai, Y.J. Yang, Z.M. Zou. Hunan Electric Power, 32(2): 47-52 (2012)
10. D.L. Wu, J. Wang, G.X. Zhang, X.J. He, K.W. Kang. 3: 46-50 (2014)

11. Y.L. Cheng. Power Generation \& Air Condition, 37(4): 14-20 (2016)

12. Y. Deng. North China Electric Power University (2015)

13. S.C. Ma, X. Jin, Y.X. Sun, J.W. Cui. Thermal Power Generation, 39(8): 12-17 (2010)

14. H.X. Liu. North China Electric Power University (2017)

15. L.J. Zhong, Y.B. Song. Thermal Power Generation, 41(8): 45-50 (2012)

16. Q.S. Jin, Z.L. Yin. Jiangsu Electrical Engineering, 34(1): 78-80 (2015)

17. Y. Zhou. Guangdong Chemical Industry, 43(10): 185-188 (2016)

18. J. Li, W.P. Yan, B.T. Gao, C. Li. Boiler Technology, 40(5): 14-17 (2009)

19. Q.G. Fan, W.P. Yan. Principles of Boiler[M]. China Electric Power Press (2004) 